\title{
MODELING AND IMPROVING SPRINKLING PROCESS WITH EJECTION NOZZLES
}

\author{
Andrey Novikov ${ }^{1,2,3}$, Anton Poddubsky ${ }^{3}$, Sergey Grigorov $^{4}$, Maksim Ratanov $^{4}$, \\ Maksim Filimonov ${ }^{1,2}$, Olga Poddubskaya ${ }^{5}$ \\ ${ }^{1}$ Volgograd State Technical University, Russia; ${ }^{2}$ Federal State Budget Scientific Institution the All- \\ Russian research institute of irrigated agriculture, Russia; \\ ${ }^{3}$ Peoples' Friendship University of Russia, Russia; ${ }^{4}$ Volgograd State Agricultural University, Russia; \\ ${ }^{5}$ State University of Humanities and Technology, Russia \\ a.poddubskiy@mail.ru
}

\begin{abstract}
The chemical-technogenic strategy of intensifying agriculture on irrigated lands based on the use of energy-rich wide-sprinkling machines with elements of irrigation technology inconsistent with agrotechnical requirements provoked the intensification of erosion processes. At the same time sprinkling as the most perfect method of irrigation prevails over the others, because it simulates natural processes of adding moisture to the soil. When raindrops affect the soil, the structure of soil aggregates destroys, particles release and microparticles are transported together with the raindrops being sprayed. To reduce the negative impact of the sprinkling process we designed the ejection nozzle, which can be used on drum-type irrigation systems with consoles (for example, DSHF 90 Agros, DSHF 110 Agros), on wide-reach machines with reduced pressure (for example, "Fregat-N", EDM "Kuban-L", "Kuban-LK"), on small-sized machines based on the units "Kuban", "Frigate". Sprinkling with a water-air mixture in comparison with nozzles without air ejection allows to reduce the size of the raindrop from 24 to $36 \%$, and to expand the area of capture by rain by $12 \%$. Modernization of sprinkling machines by ejection nozzles provides an increase in the effective irrigation coefficient to 0.75 .
\end{abstract}

Keywords: sprinkling, nozzle, deflector, ejection, impact energy, sharp edge.

\section{Introduction}

In Russia about $70 \%$ of arable land is in the zone of risky farming due to the hydrothermal climate intensity. The main limiting factor here is the lack of moisture in plants during the critical periods of their development, so obtaining significant amounts and crop production of high quality remains possible only on irrigated lands [1;2]. However, the chemical-technogenic strategy of intensifying agriculture on these lands based on the use of energy-rich wide-sprinkling machines with elements of irrigation technology inconsistent with agrotechnical requirements provoked the intensification of erosion processes and led to various types of soil degradation and a drop in soil fertility [3-5].

Irrigation, irrigation water and its quality have a significant impact on the agrophysical properties of the soil, as well as its biochemical processes of transformation of organic matter into mineral compounds and humus, determining the dynamics of soil fertility. At the same time sprinkling as the most perfect method of irrigation, simulating natural processes of moisture introduction into the soil prevails on irrigated lands of Russia. The widespread use of sprinkling is determined by high labor productivity, relatively good uniformity of water distribution over the irrigated area, high level of mechanization and automation of the process and adaptability of machines to the terrain and slopes [68]. However, the existing sprinkler technology does not provide ecological balance and soil fertility preservation during irrigation, which is manifested in degradation of their relief, formation of liquid and solid runoff on irrigated lands and, accordingly, under-watering of agricultural crops [9-13].

\section{Materials and methods}

Relevance. The entrainment of soil particles largely depends on the size and speed of flight of drops and the rain intensity. In this case the most favorable for plants and soil is drizzling rain with a diameter of drops not more than $0.9 \mathrm{~mm}$. At the moment of impact of a drop on the soil, which has a considerable energy, the structure of soil aggregates destroys, particles release and microparticles are transported together with the sprayed raindrops. When the intensity of artificial rain and the rate of water absorption by the soil exceed the surface, runoff begins to form [3;14].

It is established that under the influence of rain soil aggregates from the surface layer to the depth of $30 \mathrm{~mm}$ are destroyed, which leads to the formation of a soil crust (soil flooding) due to the blockage of macropores with oozy fractions. This problem is particularly relevant in clayey soils with low humus content and low natural fertility $[6 ; 9]$. 
Thus, by improving the moisture supply of agricultural crops, creating favorable moisture conditions for their growing season, the practice shows that irrigation also has negative consequences that require their consideration in the development of the sprinkler technology.

Task. The main qualitative indicators of artificial rain are its intensity and structure $[6 ; 7 ; 15]$. Studies of the characteristics of rain produced by nozzles without ejection and with air ejection were carried out on a test bench (Fig. 1) in accordance with the standard [16]. For stable air suction and prevention of vacuum breakdown the working pressure in the system was maintained at $0.1 \mathrm{MPa}$. The height of the nozzles from the surface was $1.5 \mathrm{~m}$.

The intensity of rain was calculated by the formula:

$$
\rho=\frac{V}{F \tau},
$$

where $V$-volume of water in the rain gauge, $\mathrm{mm}^{3}$;

$F$ - receiving area of the rain gauge, $\mathrm{mm}^{2}$.

$\tau$ - sprinkling time (filling rain gauges for $80 \%$ of their volume), min.

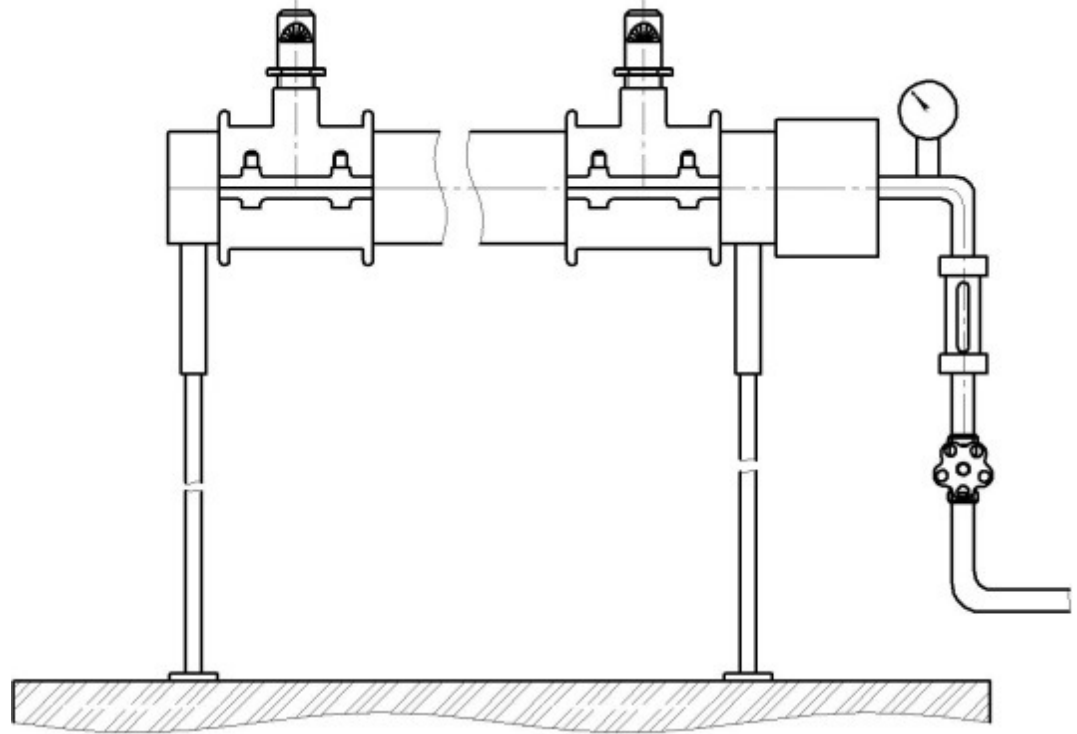

Fig. 1. Scheme of test bench for study of elements of irrigation technology of rain-forming tips

Theoretical part. The process of sprinkling from the position of elementary components is described by the effect of a raindrop on a soil aggregate. This impact is characterized by the impact energy, which mathematically for a single drop can be represented as:

$$
E_{k}=2 \rho_{k} v_{k}^{2} / 3,
$$

where $\rho_{k}=\gamma_{k} / g-$ drop density, $\mathrm{kg} \cdot \mathrm{m}^{-3}$;

$\gamma_{k}$ - specific gravity of the drop, $\mathrm{N} \cdot \mathrm{m}^{-3}$;

$g=9.81-$ acceleration of free fall, $\mathrm{m} \cdot \mathrm{s}^{-2} ;$

$v_{k}$ - speed of movement of the drop in the air, $\mathrm{m} \cdot \mathrm{s}^{-1}$.

From the theory of jet decay [17], the stability of a droplet moving in air will remain until the external forces from the air pressure

$$
p_{\xi}=\rho_{\xi} C_{x} v_{k}^{2},
$$

does not exceed the force of the internal pressure in a drop -

$$
p_{k}=4 \alpha_{k} / d_{k} \text {. }
$$

Then, equating the dependences (3) and (4) we obtain the square of the maximum velocity of the drop: 


$$
v_{k}^{2}=\frac{4 \alpha_{k}}{\rho_{\xi} C_{x} d_{k}},
$$

where $\alpha_{k}$ - coefficient of the surface tension of the drop, $\mathrm{N} \cdot \mathrm{m}^{-1}$;

$\rho_{\xi}=\gamma_{\xi} / g-$ air density, $\mathrm{kg} \cdot \mathrm{m}^{-3}$

$\gamma_{\xi}$ - specific gravity of air, $\mathrm{N} \cdot \mathrm{m}^{-3}$;

$C_{x}$ - aerodynamic coefficient of air resistance;

$d_{k}$ - droplet diameter, $\mathrm{m}$

On the other hand, considering the condition of equality of the weight of a drop -

$$
G_{k}=\pi d_{k}^{3} \gamma_{k} / 6
$$

to the air resistance force -

$$
F_{\xi}=\pi d_{k}^{2} \rho_{\xi} C_{x} v_{k}^{2} / 4
$$

we obtain the following relationship to determine the square of the maximum velocity of the drop:

$$
v_{k}^{2}=\frac{2 \rho_{k} g d_{k}}{3 \rho_{\xi} C_{x}} .
$$

Solving together equations (5) and (8) with respect to the diameter of the drop, we obtain:

$$
d_{k}=\sqrt{\frac{6 \alpha_{k}}{\rho_{k} g}} .
$$

Substituting the values $\alpha \mathrm{k}$ and $\rho \mathrm{k}$ in the formula (9) at an average air temperature of $25{ }^{\circ} \mathrm{C}$ $\left(\alpha_{k}=71.97 \mathrm{mN} \cdot \mathrm{m}^{-1}, \rho_{k}=997.07 \mathrm{~kg} \cdot \mathrm{m}^{-3}\right)$, we obtain the maximum drop diameter $d_{k}=6.6 \mathrm{~mm}$, which significantly exceeds the agrotechnical safe values $-1.5-2.0 \mathrm{~mm}$.

The analysis of the obtained mathematical dependences shows that with a decrease in the density and surface tension of a drop, its diameter and, accordingly, the impact energy on soil aggregates in the process of sprinkling decrease. The study proved that this is achievable by adding surfactants to water [18]. The most appropriate solution to this issue from the standpoint of energy efficiency and environmental friendliness is the design of ejection nozzles. The inflow of air into the rain-forming nozzle regardless of the design of the sprinkler makes it possible to obtain a mixture of water with air at the outlet, which due to its physical properties will contribute to formation of droplets of smaller diameter [19-21].

\section{Results and discussion}

When the fluid moves inside the outer cylindrical nozzle with a sharp inlet edge, a compressed section is formed with a vacuum of $0.75-0.80$ of the pressure in front of it. This phenomenon leads to the increase in the difference in the head and jet velocity in the compressed section [22;23]. Then it is logical to assume that the connection through a channel of the compressed section with the atmosphere will provide the necessary air leaks inside the nozzle and formation of water-air mixture. Given that the jet outflows into the atmosphere, then by limiting the working pressure in front of the nozzle to 1.0 MPa, it can be guaranteed that it will work with a full cross section and there will not be a breakdown of the vacuum.

The model of the rain-forming nozzle with air ejection is shown in Figure 2 [24].

When designing the nozzle, we were guided by the following principles:

1. diameter $d_{1}=4-8 \mathrm{~mm}$ and length $l_{1}=(3-4) \cdot d_{1}$ of the outer cylindrical nozzle were taken from the experience of designing rain-forming devices;

2. diameter of the radial holes $d_{2}=0.2 \cdot d_{1}$ was taken from the condition that the total area of their cross section should be less than the difference of the areas of the diameters of the nozzle and the compressed jet section $\left(S_{\Sigma}<S_{d 1}-S_{S S}\right)$; 
3. distance from the sharp edge of the inlet of the external cylindrical nozzle to the radial holes $l_{2}=(0.5-1.5) \cdot d_{1}$ is the distance over which there is an area with maximum vacuum [22];

4. triangular grooves with the depth $h_{1}$ from 0 to $1.5-2.0 \mathrm{~mm}$ with a pitch of $\approx 2 \mathrm{~mm}$ for nozzles with a fixed deflector ensure the formation of compact streams and optimal values of the quality indicators of artificial rain;

5. deflector in the form of a curved surface with structurally selected parameters - radius $R_{1}=10 \cdot d_{1}$, width $b_{2}=(3-5) \cdot d_{1}$, depth $h_{2}=3.5-5.0 \mathrm{~mm}$, with a girth angle $\varphi=155^{\circ}-170^{\circ}$ and with a displaced center located at an angle $\delta=40^{\circ}-60^{\circ}$ with respect to a flat platform due to the spoon-shaped torch of rain and the absence of pressure losses during jet departure, provides the least energy for splitting the jet, the greatest range of the droplets and the area of capture by the rain;

6. flat platform located under the outlet of the external cylindrical nozzle with structurally selected parameters - length $l_{3}=10 \mathrm{~mm}$ and width $b_{1}=(2-3) \cdot \mathrm{d}_{1}$, and the tides, symmetrical and equidistant from its axis, provide the necessary strength of the product.
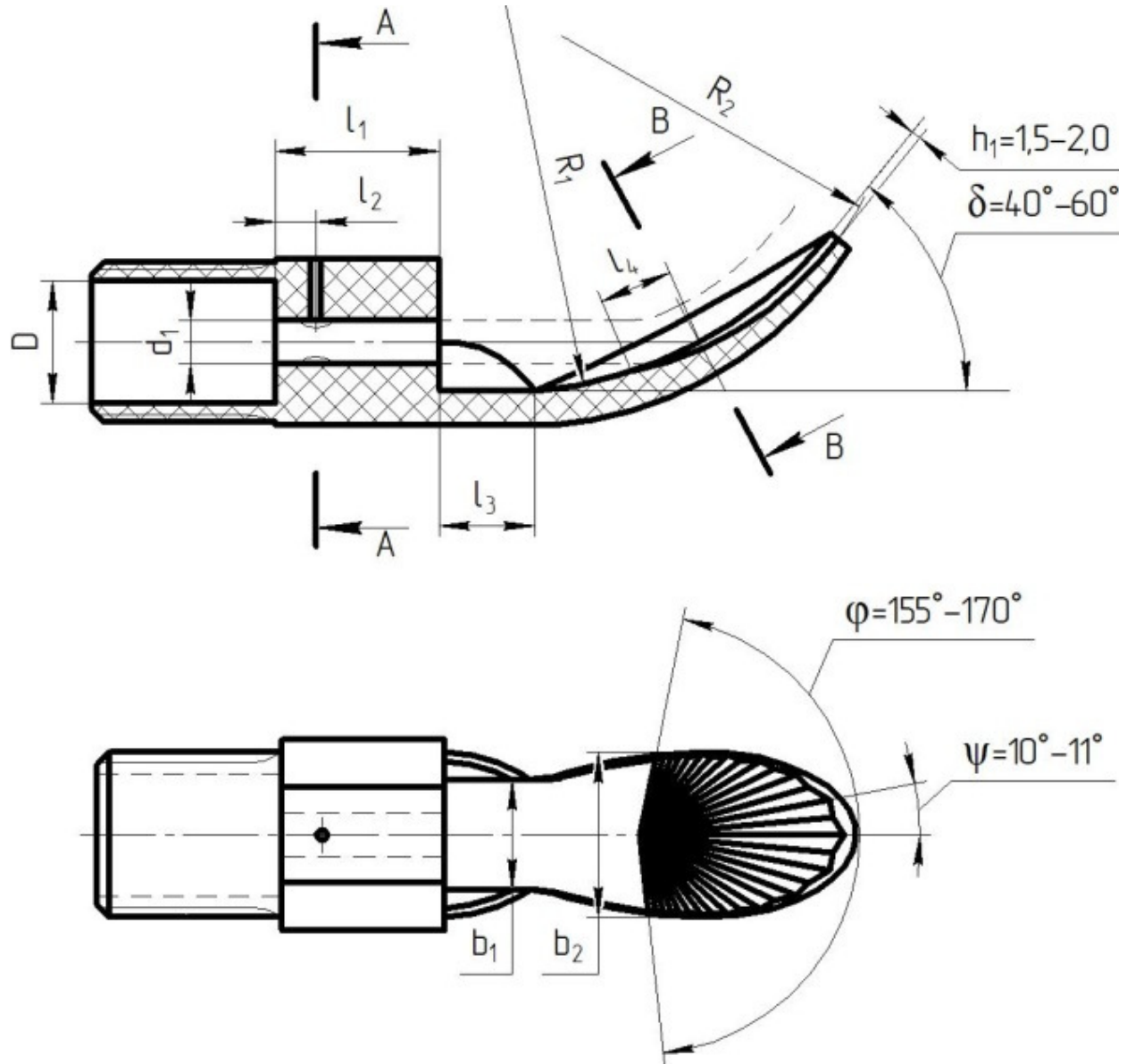

A-A

B-B (2:1)
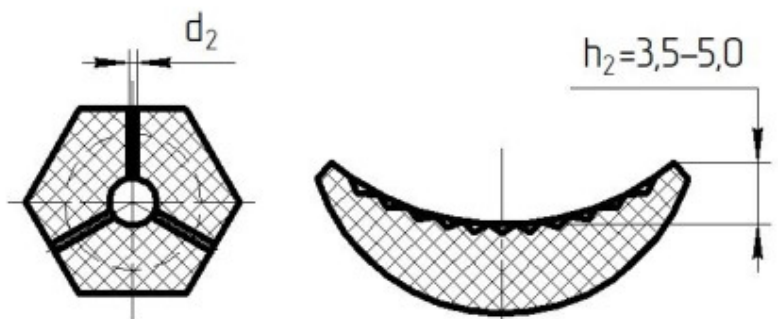

Fig. 2. Model of rain-forming nozzles with air ejection [24]

Table 1 shows the standardized range of a standardized nozzle designed for low-pressure sprinkler machines with a pressure in front of the nozzle 0.05-0.15 MPa and 0.35-0.40 MPa (35-40 m) on the 
hydrant, and Figure 3 shows the diameter and the range of the raindrops without ejection and with air ejection for the designed nozzle.

Table 1

Size range of unified nozzle

\begin{tabular}{|c|c|c|c|c|c|c|c|c|c|c|}
\hline $\begin{array}{c}\boldsymbol{d}_{\mathbf{1}}, \\
\mathbf{m m}\end{array}$ & $\begin{array}{c}\boldsymbol{D}, \mathbf{m m} \\
(\mathbf{3 - 4}) \cdot \boldsymbol{d}_{\mathbf{1}}\end{array}$ & $\begin{array}{c}\boldsymbol{i}_{\mathbf{1}}, \mathbf{m m} \\
(\mathbf{3 - 4}) \cdot \boldsymbol{d}_{\mathbf{1}}\end{array}$ & $\begin{array}{c}\boldsymbol{d}_{\mathbf{2}}, \mathbf{m m} \\
\mathbf{0 . 2} \boldsymbol{d}_{\mathbf{1}}\end{array}$ & $\begin{array}{c}\boldsymbol{l}_{\mathbf{2}} \mathbf{\mathbf { m m }} \\
\mathbf{0 . 5} \cdot \boldsymbol{d}_{\mathbf{1}}\end{array}$ & $\begin{array}{c}\boldsymbol{R}_{\mathbf{1}}, \mathbf{m m} \\
\mathbf{1 0} \cdot \boldsymbol{d}_{\mathbf{1}}\end{array}$ & $\begin{array}{c}\boldsymbol{R}_{\mathbf{2}}, \mathbf{m m} \\
\mathbf{8} \cdot \boldsymbol{d}_{\mathbf{1}}\end{array}$ & $\begin{array}{c}\boldsymbol{l}_{\mathbf{3}}^{* * *} \\
\mathbf{m m}\end{array}$ & $\begin{array}{c}\boldsymbol{l}_{\mathbf{4}}, \mathbf{m m} \\
(\mathbf{1 . 5}-\mathbf{2} \mathbf{0}) \cdot \boldsymbol{d}_{\mathbf{1}}\end{array}$ & $\begin{array}{c}\boldsymbol{b}_{\mathbf{1}}, \mathbf{m m} \\
(\mathbf{2 - 3}) \cdot \boldsymbol{d}_{\mathbf{1}}\end{array}$ & $\begin{array}{c}\boldsymbol{b}_{\mathbf{2}}, \mathbf{m m} \\
(\mathbf{3 - 5}) \cdot \boldsymbol{d}_{\mathbf{1}}\end{array}$ \\
\hline 4 & 16 & 16 & 0.8 & 2.0 & 40 & 32 & 10 & $6.0-8.0$ & 12.0 & 20 \\
\hline 5 & 20 & 20 & 1.0 & 2.5 & 50 & 40 & 10 & $7.5-10.0$ & 12.0 & 20 \\
\hline 6 & 20 & 24 & 1.2 & 3.0 & 60 & 48 & 10 & $9.0-12.0$ & 14.0 & 22 \\
\hline 7 & 22 & 24 & 1.4 & 3.5 & 70 & 56 & 10 & $10.5-14.0$ & 14.0 & 22 \\
\hline 8 & $22 *$ & 24 & 1.6 & 4.0 & 80 & 64 & 10 & $12.0-16.0$ & 16.0 & 24 \\
\hline
\end{tabular}

*Size is selected based on the strength of the seat.

**Size is selected constructively.

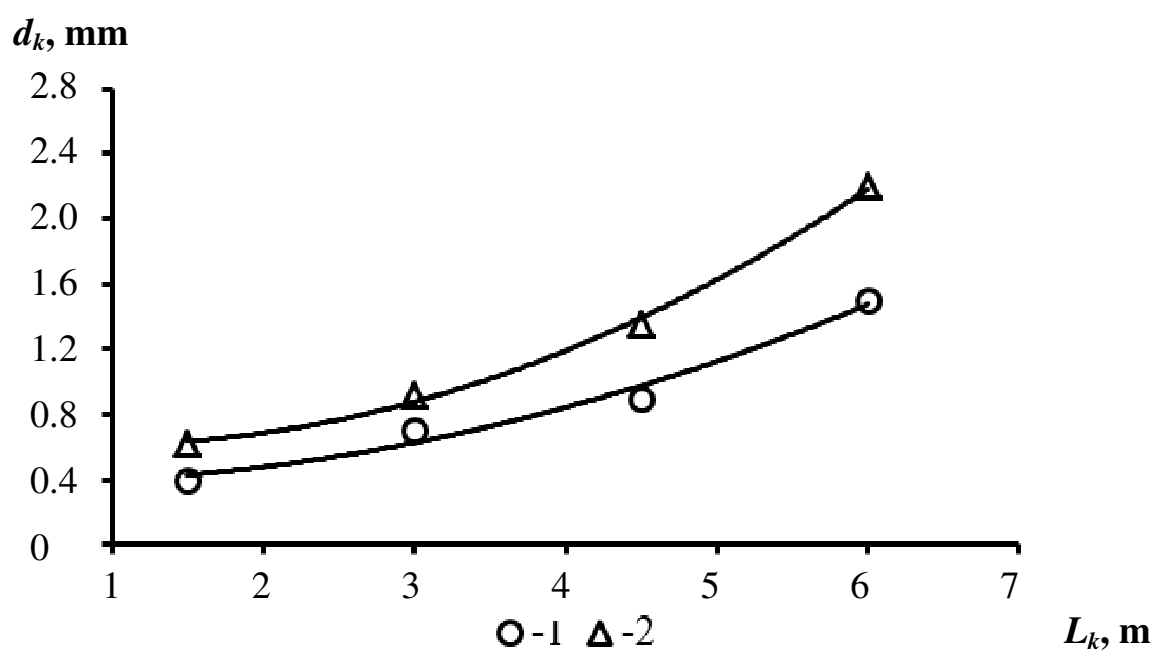

Fig. 3. Diameter and range of droplets without ejection (1) and with ejection (2) of air

\section{Conclusions}

The worked out nozzle design can be used on drum-type irrigation systems with consoles (for example, DSHF 90 Agros, DSHF 110 Agros), on wide-reach machines with reduced pressure (for example, "Fregat-N", EDM "Kuban-L", "Kuban-LK"), on small-sized machines based on the units "Kuban", "Frigate". Sprinkling with a water-air mixture in comparison with nozzles without air ejection allows to reduce the size of the raindrop from 24 to $36 \%$, and to expand the area of capture by rain by $12 \%$. Modernization of sprinkling machines by ejection nozzles provides an increase in the effective irrigation coefficient to 0.75 .

\section{Acknowledgements}

The publication has been prepared with the support of the "RUDN University Program 5-100".

\section{References}

[1] Кружилин И.П. Научное обоснование дождевальной техники и режимов орошения сельскохозяйственных культур в Нижнем Поволжье: рекомендации (Scientific substantiation of sprinkling equipment and crop irrigation regimes in the Lower Volga region: recommendations) / И. П. Кружилин, В. В. Мелихов, Т. Н. Дронова и др. / ВНИИОЗ. Волгоград, 2015. 36 c. (In Russian)

[2] Li F., Liang X., Chen K. (2013) The application analysis of sprinkling and drip irrigation technology in the ecological environment construction. Advanced Materials Research. 2013 Vol. 684. pp. 242-245. 
[3] Егоров И. Е. Капельно-дождевая эрозия - рельефообразующее значение и методы изучения (Drip-rain erosion - relief-forming significance and methods of study) // Вестник Удмуртского университета. 2015. Т. 25, Вып. 2. С. 159-166. (In Russian)

[4] Воеводина Л. А. Структура почвы и факторы, изменяющие ее при орошении (Soil structure and factors changing it during irrigation) // Научный журнал Российского НИИ проблем мелиорации. 2016. № 1 (21). С. 134-154. (In Russian)

[5] Воеводина Л. А. Структурное состояние черноземов обыкновенных в орошаемых и неорошаемых условиях (Structural condition of ordinary chernozems in irrigated and nonirrigated conditions) // Научный журнал Российского НИИ проблем мелиорации. 2016. № 2 (22).C. 41-55. (In Russian)

[6] Поспелов А. М. Дождевание (Sprinkling) / А.М. Поспелов. Москва: Сельхозгиз, 1952. 160 с. (In Russian)

[7] Мелиорация и водное хозяйство. Орошение: Справочник (Melioration and water management. Irrigation: A Handbook) / П. А. Айдаров, К. П. Арент, В. Н. Басс и др.; под ред. Б. Б. Шумакова. Москва: Колос, 1999. 432 с. (In Russian)

[8] Проектирование и расчет систем дождевания и капельного орошения сельскохозяйственных культур: методическое пособие (Design and calculation of irrigation systems and drip irrigation of agricultural crops: a manual) / В.В. Мелихов, И.П. Кружилин, Н.Н. Дубенок и др. / ВНИИОЗ. Волгоград: ООО «СФЕРА», 2017. 168 с. (In Russian)

[9] Абрамов А. М. Определение параметров впитывания воды в почву с учетом энергетических характеристик дождя (Determination of Parameters of Water Absorption into the Soil with Consideration of the Energy Characteristics of Rain) // Почвоведение. 1985. № 6. C. 137-143. (In Russian)

[10] Битюков К. Г. Сохранение структуры почв при орошении дождеванием (Preservation of soil structure during irrigation with sprinkling) // Гидротехника и мелиорация. 1951. № 5. С. 24-34. (In Russian)

[11] Снипич Ю. Ф., Шепелев А.Е. Применение основных законов дождевания при обосновании конструкции ДМ «ДКФ-1ПК-1» (The application of the basic laws of sprinkling when justifying the construction of DM “DKF-1PK-1" ) // Мелиорация и водное хозяйство. 2006. № 4. С. 5758. (In Russian)

[12] Abdrazakov F. K., Zatinatsky S. V., Povarov A. V. et al. Hydrodynamic model of watering of the fregat sprinkling system equipped with deflector nozzles International // Journal of Pharmacy and Technology. 2016. Vol. 8(4). pp. 27063-27071.

[13]Губер К. В., Лямперт Г. П., Храбров М. Ю. Требования к характеристикам дождя при создании дождевальной техники . (Irrigation erosion of irrigated soils in the foothills of southern Kazakhstan) // Современные проблемы мелиораций и пути их решения: юбилейный сб. науч. тр. / РАСХН, ВНИИГиМ. М., 1999. Т. 1 (98). С. 187-199 (In Russian)

[14] Huber K. V., Lyampert P. P., Khrabrov M. Yu. Requirements for the characteristics of rain when creating sprinkler technology // Modern problems of land reclamation and ways to solve them: jubilee collection. scientific tr. / RAAS, VNIIGiM. Moscow, 1999. Vol. 1 (98). pp. 187-199.

[15]Boja N., Boja F., Teusdea A. et al. Research regarding the uniformity of sprinkler irrigation // Journal of Environmental Protection and Ecology. 2013. Vol. 14 (4). pp. 1661-1672.

[16]СТО АИСТ 11.1-2010. Испытания сельскохозяйственной техники. Машины и установки дождевальные. Методы оценки функциональных показателей. Взамен СТО АИСТ 11.12004. Введен 15.04.2011. STO AIST 11.1-2010. Tests of agricultural machinery. Machines and installation sprinkler. Methods for assessing functional indicators. Introduced 04.15.2011. (In Russian)

[17] Лебедев Б. М. Дождевальные машины (Sprinkling machines). Москва: «Машиностроение», 1977. 244 c. (In Russian)

[18] Lehrsch G. A., Sojka R. E., Reed J. L. et al. Surfactant and irrigation effects on wettable soils: Runoff, erosion, and water retention responses // Hydrological Processes. 2011. Vol. 25 (5). pp. 766-777.

[19]Новиков А. Е., Константинова Т. Г., Ламскова М. И. Модернизация дождевальных машин дефлекторными эжекторными насадками с малоэнергоемким искусственным дождем (Modernization of sprinkling machines by deflector ejector nozzles with low-power-intensive 
artificial rain) // Водоочистка. Водоподготовка. Водоснабжение. 2013. № 8. С. 18-20. (In Russian)

[20] Borodychev V. V., Novikov A. E., Filimonov M. I. et al. Study of low power-consuming artificial rain nozzle // Scientific Life 2016. No 2. pp. 50-57.

[21] Мамедов Н. А., Гарибов Г. И., Алекберов Ш. Ш., Расулов Э. А. Изменение поверхностного натяжения воды под действием различных физических факторов .(Changes in the surface tension of water under the action of various physical factors) // Прикладная физика. 2014. № 6. C. 20-23 (In Russian)

[22] Сиов Б. Н. Истечение жидкости через насадки в среды с противодавлением (Flow of fluid through nozzles into media with counterpressure). Москва, Машиностроение, 1968. 140 c. (In Russian)

[23]Справочник по гидравлическим расчетам (Handbook of hydraulic calculations) / П. Г. Киселев, А. Д. Альтшуль, Н. В. Данильченко и др.; под ред. П. Г. Киселева. Москва: «Энергия», 1972. -312 с. (In Russian)

[24]Патент Российской Федерации на п.м. № 173276, МПК В05В 1/18. Насадка короткоструйная дефлекторная / А.Е. Новиков, М.И. Филимонов, Т.Г. Константинова и др.. Опубликовано 21.08.2017. (The patent of the Russian Federation on m. No. 173276, IPC B05B 1/18. Nozzle short-jet deflector / A. E. Novikov, M. I. Filimonov, T. G. Konstantinova et al. Posted on 08.21.2017) (In Russian) 